Original scientific paper - Izvorni znanstveni rad

UDK: 637.146 .34

\title{
Influence of fortification with inulin and Hi-maize on textural and sensory properties of set-type probiotic yoghurt
}

doi: $10.15567 /$ mljekarstvo.2018.0304

Gülfem Unal*, Elif Ozer

Ege University, Faculty of Agriculture, Department of Dairy Technology, 35100 Bornova, Izmir, Turkey

Received - Prispjelo: 28.07.2017.

Accepted - Prihvaćeno: 18.04.2018.

\begin{abstract}
The aim of this research was to investigate the effect of fortification with inulin and resistant starch (Hi-maize) on textural and sensory properties of set-type probiotic yoghurt containing Lactobacillus acidophilus during 21 days of storage. Textural characteristics were evaluated by determining firmness, adhesiveness and apparent viscosity parameters. Milk was fortified with inulin or Hi-maize at $2 \%$ or $4 \%$ ratios, whereas the control group had no supplement. Probiotic yoghurt supplemented with $2 \%$ Hi-maize was firmer than that supplemented with $2 \%$ inulin, except at the beginning of storage. There were no significant differences among the firmness values of yoghurt samples fortified by inulin and Hi-maize when the ratio increased to $4 \%$. The addition ratio of inulin or Hi-maize did not significantly affect adhesiveness. Supplementation with $2 \%$ inulin or Hi-maize did not alter viscosity of yoghurts at most of the storage days. Sensory attributes were evaluated as taste, appearance, aroma, texture and overall acceptability. In general, there were no significant differences in sensorial parameters between yoghurts added with inulin or Hi-maize. Neither the addition rate nor the storage period affected the sensory scores of the samples. Significant reductions $(\mathrm{P}<0.05)$ of taste, appearance, aroma and overall acceptability scores of the control probiotic yoghurt were determined at the end of storage when compared to the $1^{\text {st }}$ day.
\end{abstract}

Key words: probiotic yoghurt, prebiotic, texture, sensory characteristics

\section{Introduction}

Due to the high nutritional value yoghurt enjoys a worldwide consumption. The textural and sensory characteristics of set-type yoghurt are important quality parameters because they play an important role in consumers' acceptance of these products. In general, yoghurt which is thick and has a smooth surface without any sign of syneresis is preferred (Amatayakul et al., 2006). Good-quality yoghurt can be obtained by adding ingredients to increase the total solids of the yoghurt mix to a desired level. There are many factors that affect yoghurt quality, including the chemical composition of the milk and the methods of fortification used (GuzmanGonzález et al., 1999).
Yoghurt is very often a carrier of probiotic bacteria in order to improve its functionality and health effects. Among various probiotic microorganisms, Lactobacillus acidophilus is one of the most preferred probiotic bacteria and has been used in the manufacture of synbiotic dairy products in many studies (Akalın and Ünal, 2010; de Souza Oliveira et al., 2011; Heydari et al., 2011; Hasani et al., 2016). Among the different process parameters, such as milk base composition, heat treatment, fermentation, and storage conditions, starter culture also plays a determinative role in gel structure formation of yoghurt. As probiotic bacteria grow slowly in milk due to the lack of proteolytic enzymes, they negligibly contribute to sensory and textural 
characteristics of the product (Klaver et al., 1993; Dave and Shah, 1998a; 1998b). Therefore, the practice is to blend these organisms with a yoghurt starter culture (Damin et al., 2008; Marafon et al., 2011). Additionally in the concept of functional foods, probiotics are added to yoghurt for the prevention of disease and maintenance of health and wellbeing as a natural way of enhancing functionality.

Skim milk powder (SMP) is traditionally used to fortify yoghurt milk. However, in recent years, manufacturers have become more interested in other ingredients because of their promoting effects on various characteristics of yoghurt and nutraceutical attributes. Among these ingredients both inulin and High maize (Hi-maize) resistant starch are used for such purposes (Mohammadi and Mortazavian, 2011). Inulin which is a soluble and fermentable fibre called fructan, is produced from several fruits and vegetables (Tamime, 2005). Inulin consists of a mixture of oligomers and long polymer chains with a variable number of fructose molecules (Kavaz and Bakırc1, 2014). It has many benefits when added to yoghurt, including textural improvement, nutritional enrichment, reduced syneresis, extended shelf life, mild flavour development and potential prebiotic and nutraceutical effects (Kailasapathy and Supriadi, 1998). On the other hand, resistant starch is a small starch fraction resistant to digestion, and it can be fermented by the healthy microflora in the large intestine. By having attractive characteristics for the food industry, such as being from a natural source, possessing mild taste, and presenting a white colour and low water retention capacity, it is considered a valuable supplement in the formulation of various types of functional food (Homayouni et al., 2013).

The objective of this research was to investigate the effect of fortification with different ratios of inulin and Hi-maize resistant starch on the textural and sensory characteristics of set-type probiotic yoghurt.

\section{Materials and methods}

\section{Strains and ingredients}

The commercial yoghurt starter culture containing Streptococcus thermophilus and Lactobacillus delbrueckii subsp. bulgaricus (Lactoferm YO-195) and Lactobacillus acidophilus (Lactoferm LA) (Biochem S.r.1., Via Fratelli Rosselli, 3800015 Mon- terotondo, Rome, Italy) was in a freeze-dried direct vat set (DVS) form. Each culture was added at a content of $0.04 \mathrm{gL}^{-1}$, and was used according to the recommendation of the manufacturer. Dairy ingredients that were used included skim milk powder (Pınar Dairy Products, Izmir, Turkey), inulin (Fibruline Instant, average degree of polymerization of 10, Cosucra, Belgium) and Hi-maize (Hi-maize ${ }^{\circledR}$ 260, high amylose maize resistant starch, Ingredion, Hamburg, Germany). The nutrition labelling information stated by the manufacturer was for inulin to contain $95.8 \%$ total solids, $0 \%$ fat, $0 \%$ protein and $95.8 \%$ total carbohydrate whereas the contents of the components for Hi-maize were $88.8 \%, 0.8 \%$, $0.8 \%$ and $87 \%$, respectively.

\section{Yoghurt manufacture}

Set-type probiotic yoghurt was prepared using milk containing $3 \% \mathrm{w} / \mathrm{w}$ milk fat that was standardized with skim milk powder to obtain $110 \mathrm{gL}^{-1}$ of non-fat milk solids. The milk was divided into five lots. The control group had no supplement. The other four groups were supplemented with $2 \% \mathrm{w} / \mathrm{w}$ or $4 \% \mathrm{w} / \mathrm{w}$ inulin or Hi-maize. After they were mixed properly, each milk base was heated to $85^{\circ} \mathrm{C}$ for $30 \mathrm{~min}$ by circulation in a hot water bath. The mixtures were then cooled to $43{ }^{\circ} \mathrm{C}$ in an ice bath, and cultures were added according to the manufacturer's instructions. The mixtures were then put into plastic containers and incubated at $42{ }^{\circ} \mathrm{C}$ until a $\mathrm{pH}$ of 4.70 was reached. After fermentation, the yoghurt samples were cooled and transferred to a refrigerator and stored at $4{ }^{\circ} \mathrm{C}$ for 21 days for analyses.

\section{Compositional analyses}

The total solids were determined by drying samples at $110^{\circ} \mathrm{C}$ for $2 \mathrm{~h}$ (AOAC, 2006). Protein content was analysed by the Kjeldahl method using the Kjeltec system distillation unit (AOAC, 2006). A multiplication factor of 6.37 was used to convert percentage nitrogen to percentage protein. The fat content was analysed by the Gerber method (Renner, 1993). The total solid, protein and fat contents of the samples were determined after $24 \mathrm{~h}$ of product storage at $4{ }^{\circ} \mathrm{C}$. Analyses were performed in triplicate. 


\section{Textural properties}

Firmness and adhesiveness

The firmness of the yoghurt samples was measured with a TA-XT Plus texture analyser (Vienna Court, UK) using a single-compression cycle test with a $4.5 \mathrm{~kg}$ load cell. Pre-test and test speed were fixed at $1 \mathrm{~mm} / \mathrm{s}$, and penetration depth was $20 \mathrm{~mm}$ (Bonczar et al., 2002; Sandoval-Castilla et al., 2004). Firmness was measured as the peak compression force $(\mathrm{g})$ during the penetration of the sample, and adhesiveness as the negative peak force area (-gs) during withdrawal. The test was carried out immediately after removing the samples from the refrigerator at $4{ }^{\circ} \mathrm{C}$ every week throughout the storage period of 21 days.

\section{Viscosity}

The viscosity of the yoghurts was measured after stirring the product for $60 \mathrm{~s}$, using a Brookfield Viscometer Model DVII (Brookfield Engineering Laboratories, Middleboro, MA, USA) at $10^{\circ} \mathrm{C}$. Samples were tested using the LV4 spindle, and data were taken in duplicate at a spindle rotation of 20 revolutions per minute (rpm). The analysis was done every week during 21 days.

\section{Sensory characteristics}

Sensory evaluation of the samples was carried out according to the method modified from Turkish Yoghurt Standard (1989) and Martín-Diana et al. (2003). The panel group consisted of experienced nine academicians from the department of Dairy Technology (Ege University, Izmir, Turkey) who were familiar with attributes and scaling procedures of yoghurt samples under study. Sensory evaluation consisting of appearance, aroma, taste, texture, and overall acceptability were based on 5-point hedonic scales $(1=$ dislike extremely; $5=$ like extremely $)$. Each sample was scored individually, and the samples were presented to the panellists in the individual plastic containers. Yoghurts, coded with 3 digits, were randomly presented to the panel group at each session. Water was also presented to rinse their palates between samples. Panellists evaluated all of the samples after storage for $1,7,14$, and $21 \mathrm{~d}$ at $4{ }^{\circ} \mathrm{C}$.

\section{Statistical analysis}

The experiments were performed twice with three in parallel. Six values for each sample were averaged $(n=6)$. The data obtained were processed by one-way ANOVA using the general linear model procedure of the SPSS version 11.05 (SPSS Inc., Chicago, IL, USA). The means were compared with the Duncan test at the $\mathrm{P}<0.05$ level.

\section{Results and discussion}

\section{Composition of probiotic yoghurts}

The average compositions of probiotic yoghurts that were determined after $24 \mathrm{~h}$ of manufacture are given in Table 1 . Total solid values of the experimental yoghurts changed between 13.18 and $16.43 \%$. The highest total solid was determined in probiotic yoghurt supplemented with $4 \%$ inulin whereas the control sample had the lowest total solid $(\mathrm{P}<0.05)$. The yoghurts fortified with inulin had higher $(\mathrm{P}<0.05)$ total solids than those fortified with same ratio of Hi-maize. This is obviously attributed to higher total solids of inulin $(95.8 \%)$ than that of Hi-maize resistant starch $(88.8 \%)$. The protein content of the samples ranged from 3.00 to $3.08 \%$ and the highest protein values were observed in samples containing Hi-maize resistant starch, which can be related to the composition of resistant starch used

Table 1. Composition of probiotic yoghurts $(n=6)$

\begin{tabular}{cccc}
\hline Sample & Total solids (\%) & Protein (\%) & Fat (\%) \\
\hline C & $13.18 \pm 0.03^{\mathrm{E}}$ & $3.00 \pm 0.00^{\mathrm{B}}$ & $2.65 \pm 0.08^{\mathrm{A}}$ \\
\hline I2 & $14.75 \pm 0.08^{\mathrm{C}}$ & $3.00 \pm 0.00^{\mathrm{B}}$ & $2.74 \pm 0.00^{\mathrm{A}}$ \\
\hline I4 & $16.43 \pm 0.03^{\mathrm{A}}$ & $3.03 \pm 0.05^{\mathrm{AB}}$ & $2.73 \pm 0.02^{\mathrm{A}}$ \\
\hline HM2 & $14.17 \pm 0.07^{\mathrm{D}}$ & $3.03 \pm 0.05^{\mathrm{A}}$ & $2.68 \pm 0.12^{\mathrm{A}}$ \\
\hline HM4 & $15.32 \pm 0.32^{\mathrm{B}}$ & $3.08 \pm 0.05^{\mathrm{A}}$ & $2.69 \pm 0.04^{\mathrm{A}}$ \\
\hline
\end{tabular}

C: probiotic yoghurt with no supplement; I2: probiotic yoghurt fortified with $2 \%$ inulin; I4: probiotic yoghurt fortified with $4 \%$ inulin; HM2: probiotic yoghurt fortified with $2 \%$ Hi-maize; HM4:probiotic yoghurt fortified with $4 \%$ Hi-maize.

A-E Means \pm standard deviations in the same column with different superscript uppercase letters are significantly different $(\mathrm{P}<0.05)$ 
in the manufacture. On the other hand, there were no significant differences among yoghurt samples in terms of fat content $(\mathrm{P}>0.05)$.

\section{Textural properties}

The changes in firmness and adhesiveness of the probiotic yoghurts are shown in Fig. 1A and Fig. 1B, respectively. There were no significant $(\mathrm{P}>0.05)$ differences in firmness values between control probiotic yoghurt and yoghurt supplemented with $2 \%$ inulin during 14 days of storage. Higher firmness values were obtained for the $4 \%$ inulin added sample when compared to control

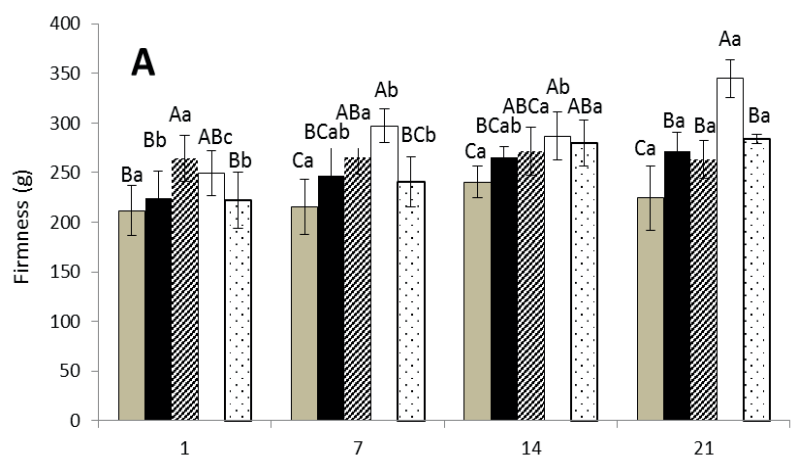

yoghurt throughout the storage period. Similar to our results, Ramchandran and Shah (2008) did not find any significant differences between firmness values of control and $2 \%$ inulin supplemented low-fat yoghurts. The addition ratio of inulin did not statistically influence the firmness of the probiotic yoghurt samples except on the $1^{\text {st }}$ day in our study. Wang et al. (2015) also could not observe any significant effect of different inulin addition levels on texture of yoghurts. Conversely, Guggisberg et al. (2009) detected a trend of an increase in firmness when the addition rate of inulin increased from $2 \%$ to $4 \%$ in set yoghurts.

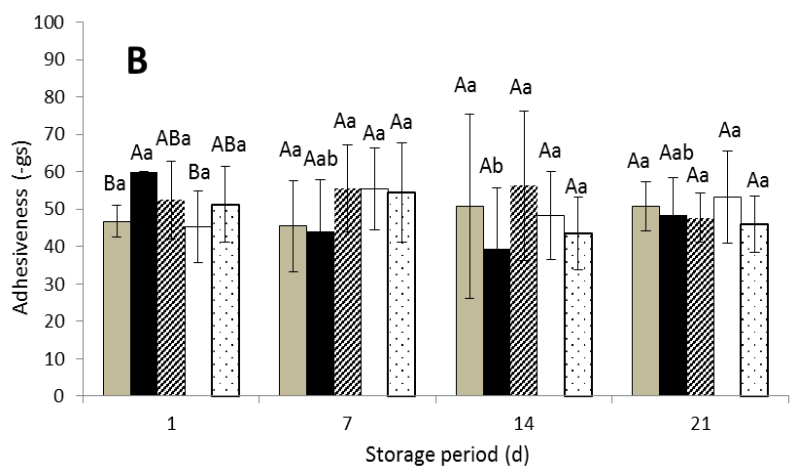

Figure 1. Firmness (A) and adhesiveness (B) in probiotic yoghurts during storage. C: probiotic yoghurt with no supplement (gray bar); I2: probiotic yoghurt fortified with $2 \%$ inulin (black bar); I4: probiotic yoghurt fortified with $4 \%$ inulin (hashed bar); HM2: probiotic yoghurt fortified with $2 \% \mathrm{Hi}$-maize (white bar); HM4: probiotic yoghurt fortified with $4 \%$ Hi-maize (dotted bar). Error bars indicate standard deviations. Different superscript lowercase letters denote significant differences between storage days for the same product $(\mathrm{P}<0.05)$. Different superscript uppercase letters denote significant differences between products for the same storage day $(\mathrm{P}<0.05)$

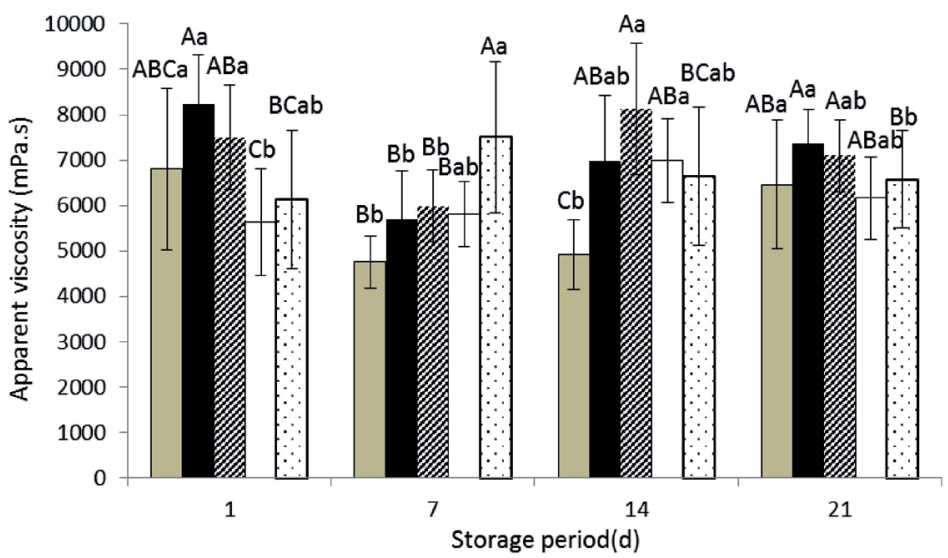

Figure 2. Apparent viscosity in probiotic yoghurts during storage. C:probiotic yoghurt with no supplement (gray bar); I2: probiotic yoghurt fortified with $2 \%$ inulin (black bar); I4: probiotic yoghurt fortified with $4 \%$ inulin (hashed bar); HM2: probiotic yoghurt fortified with $2 \%$ Hi-maize (white bar); HM4: probiotic yoghurt fortified with $4 \% \mathrm{Hi}$-maize (dotted bar). Error bars indicate standard deviations. Different superscript lowercase letters denote significant differences between storage days for the same product $(\mathrm{P}<0.05)$. Different superscript uppercase letters denote significant differences between products for the same storage day $(\mathrm{P}<0.05)$ 
The addition of inulin did not affect the adhesiveness of probiotic yoghurts, since there were no significant differences between the control yoghurt and yoghurts supplemented with inulin. In another study, the addition of inulin did not affect either firmness or adhesiveness of probiotic soy yoghurt during 28 days of storage (Bedani et al., 2014). It has been suggested that inulin is a waterstructuring agent, and may form a complex with protein aggregates in yoghurts, which could explain the increase in firmness in these products (Kip et al., 2006). Nevertheless, Kim et al. (2001) have reported that heating inulin solutions to temperatures above $80{ }^{\circ} \mathrm{C}$ causes degradation of inulin into shorter chains by hydrolysis, which makes it difficult to form gel. In addition, the authors showed that low concentrations of inulin (5\%) did not form a hard gel structure.

Supplementation with Hi-maize significantly improved the firmness of yoghurts when compared to control sample. The probiotic yoghurt supplemented with $2 \%$ Hi-maize had higher firmness values than the yoghurt supplemented with $2 \%$ inulin during the storage period. Therefore, it can be concluded that Hi-maize addition was more effective for the firmness characteristic of probiotic yoghurt at the ratio of $2 \%$. On the other hand, there were no significant differences $(\mathrm{P}>0.05)$ between the samples I4 and HM4 except at the beginning of storage. The addition of $2 \% \mathrm{Hi}$-maize increased the firmness values of the samples more than the addition of $4 \% \mathrm{Hi}$-maize on the $7^{\text {th }}$ and $21^{\text {st }}$ days of storage. This can be attributed to the lower $\mathrm{pH}$ value of sample HM4 than that of HM2 on the stated storage days (data not shown). It has been reported by Lucey and Singh (1998) that the acidification of milk causes whey separation in acid gels like yoghurt and low acidity is one of the reason for a weak and thin body in yoghurts. Less firm yoghurts were also obtained by Wang et al. (2015) as the $\mathrm{pH}$ values of the samples decreased. Moreover, Nguyen et al. (2017) reported that the addition rate of starch has importance in firmness of yoghurt, and a relatively high level of starch is required to remarkably increase the firmness characteristic of yoghurt.

Comparing days 1 and 21, there was a significant increase in firmness for samples supplemented with Hi-maize and the sample supplemented with $2 \%$ inulin. Similar results were reported by
Bedani et al. (2014) in probiotic soy yoghurt added with inulin. The storage period did not significantly alter the adhesiveness of experimental yoghurts $(\mathrm{P}>0.05)$. Bedani et al. (2014) could not detect a statistically different change in adhesiveness values of probiotic soy yoghurt added with inulin on the $14^{\text {th }}, 21^{\text {st }}$ and $28^{\text {th }}$ days of storage.

The apparent viscosity values of the samples are presented in Fig 2. In general, treatment with inulin as well as the rate of inulin did not affect the apparent viscosity of probiotic yoghurts significantly $(P>0.05)$. Akalın et al. (2008) also did not detect any effect of fructooligosaccharide supplementation, which is an inulin-type prebiotic, on viscosity values of reduced-fat probiotic yoghurt. Similarly, there were no significant differences between the apparent viscosity values of low-fat set yoghurt with probiotic cultured banana purée fortified with $1 \%, 2 \%$ and $3 \%$ inulin (Srisuvor et al., 2013). Balthazar et al. (2015) on contrary detected a significant increase in apparent viscosity in ovine milk yoghurt when the addition ratio of inulin increased from $2 \%$ to $6 \%$. This contradiction with our study can be attributed to the higher addition ratio of inulin, total solid level of the samples and degree of polymerization of inulin in that study. Pimentel et al. (2012) also reported that degree of polymerization of inulin-type fructans can have a notable effect on the rheological characteristics of probiotic yoghurt. Additionally, Sodini et al. (2002) reported that the rheological parameters of probiotic fermented milks were influenced strongly by the starter culture and the milk base.

In general, supplementation with Hi-maize did not change the viscosity characteristic of probiotic yoghurts significantly $(\mathrm{P}>0.05)$ when compared to the control sample. This was expected since Himaize resistant starch has been reported to have a low water retention capacity (Homayouni et al., 2013). No significant differences were found between the viscosity values of the samples HM2 and HM4 except at the $7^{\text {th }}$ day. Similarly, viscosity of low-fat yoghurt did not significantly change when the addition ratio of modified starch increased from $0.5 \%$ to $1.5 \%$ (Nguyen et al., 2017). The authors also stated that modified starch can improve the firmness of the yoghurt without causing significant changes in the product rheology. That way differences between firmness and apparent viscosity 
values in our probiotic yoghurt samples fortified with Hi-maize could be explained. In general, similar results were obtained between apparent viscosity values of control probiotic yoghurt and probiotic yoghurts whether fortified with inulin or Hi-maize in our study.

Although a fluctuation was observed in the viscosity of all experimental probiotic yoghurts, there was no significant difference between the $1^{\text {st }}$ and $21^{\text {st }}$ days of storage. In parallel to our results, no great differences were noticed among viscosities of probiotic fermented milk products that supplemented with inulin after the $1^{\text {st }}$ and $20^{\text {th }}$ days of storage in another study (Stijepic et al., 2013). Similarly, Modzelewska-Kapitula and Klebukowska (2009) did not find any significant difference in apparent viscosities of yoghurts supplemented with $0.7 \%$ or $2.7 \%$ inulin between the beginning of storage and the $21^{\text {st }}$ day.

\section{Sensory characteristics}

Sensory characteristics of the experimental samples during storage are given in Table 2. In general, addition of inulin did not influence taste, appearance or overall acceptability during 14 days

Table 2. Sensory properties of probiotic yoghurts during storage $(n=9)$

\begin{tabular}{|c|c|c|c|c|}
\hline \multirow[b]{2}{*}{ Sample } & \multicolumn{4}{|c|}{ Storage days } \\
\hline & 1 & 7 & 14 & 21 \\
\hline & \multicolumn{4}{|c|}{ Taste } \\
\hline $\mathrm{C}$ & $4.42 \pm 0.49^{\mathrm{Aa}}$ & $4.67 \pm 0.26^{\mathrm{Aa}}$ & $4.13 \pm 0.63^{\mathrm{Aa}}$ & $3.38 \pm 0.86^{\mathrm{Bb}}$ \\
\hline $\mathrm{I} 2$ & $4.67 \pm 0.52^{\mathrm{Aa}}$ & $4.79 \pm 0.40^{\mathrm{Aa}}$ & $4.38 \pm 0.45^{\mathrm{Aa}}$ & $4.38 \pm 0.377^{\mathrm{Aa}}$ \\
\hline I4 & $4.22 \pm 0.75^{\mathrm{Aab}}$ & $4.71 \pm 0.40^{\mathrm{Aa}}$ & $4.50 \pm 0.32^{\mathrm{Aab}}$ & $3.75 \pm 0.81^{\mathrm{ABb}}$ \\
\hline HM2 & $4.42 \pm 0.49^{\mathrm{Aa}}$ & $4.33 \pm 0.61^{\mathrm{ABa}}$ & $4.08 \pm 0.58^{\mathrm{Aab}}$ & $3.62 \pm 0.37^{\mathrm{ABb}}$ \\
\hline \multirow[t]{2}{*}{ HM4 } & $3.92 \pm 0.20^{\mathrm{Aa}}$ & $4.00 \pm 0.45^{\mathrm{Ba}}$ & $3.83 \pm 0.52^{\mathrm{Aa}}$ & $3.62 \pm 0.37^{\mathrm{ABa}}$ \\
\hline & \multicolumn{4}{|c|}{ Appearance } \\
\hline $\mathrm{C}$ & $4.83 \pm 0.41^{\mathrm{Aa}}$ & $4.75 \pm 0.42^{\mathrm{Aab}}$ & $4.75 \pm 0.42^{\mathrm{Aab}}$ & $4.25 \pm 0.39^{\mathrm{cb}}$ \\
\hline $\mathrm{I} 2$ & $5.00 \pm 0.00^{\mathrm{Aa}}$ & $4.75 \pm 0.42^{\mathrm{Aa}}$ & $4.83 \pm 0.26^{\mathrm{Aa}}$ & $4.75 \pm 0.39^{\mathrm{ABa}}$ \\
\hline I4 & $4.67 \pm 0.82^{\mathrm{Aa}}$ & $4.83 \pm 0.26^{\mathrm{Aa}}$ & $4.75 \pm 0.42^{\mathrm{Aa}}$ & $4.75 \pm 0.39^{\mathrm{ABa}}$ \\
\hline HM2 & $4.92 \pm 0.20^{\mathrm{Aa}}$ & $4.50 \pm 0.55^{\mathrm{Aa}}$ & $4.67 \pm 0.52^{\mathrm{Aa}}$ & $4.50 \pm 0.45^{\mathrm{BCa}}$ \\
\hline \multirow{2}{*}{ HM4 } & $4.83 \pm 0.41^{\mathrm{Aa}}$ & $4.50 \pm 0.77^{\mathrm{Aa}}$ & $4.67 \pm 0.52^{\mathrm{Aa}}$ & $5.00 \pm 0.00^{\mathrm{Aa}}$ \\
\hline & \multicolumn{4}{|c|}{ Aroma } \\
\hline $\mathrm{C}$ & $4.17 \pm 0.68^{\mathrm{Aa}}$ & $4.42 \pm 0.38^{\mathrm{Aa}}$ & $4.33 \pm 0.49^{\mathrm{Aa}}$ & $3.83 \pm 0.86^{\mathrm{Ab}}$ \\
\hline $\mathrm{I} 2$ & $4.50 \pm 0.84^{\mathrm{Aa}}$ & $4.50 \pm 0.45^{\mathrm{Aa}}$ & $4.55 \pm 0.34^{\mathrm{Aa}}$ & $4.12 \pm 0.66^{\mathrm{Aa}}$ \\
\hline I4 & $4.17 \pm 0.98^{\mathrm{Aab}}$ & $4.58 \pm 0.38^{\mathrm{Aa}}$ & $4.33 \pm 0.41^{\mathrm{Aab}}$ & $3.62 \pm 0.37^{\mathrm{Ab}}$ \\
\hline HM2 & $4.33 \pm 0.75^{\mathrm{Aa}}$ & $4.33 \pm 0.75^{\mathrm{Aa}}$ & $4.25 \pm 0.52^{\mathrm{Aa}}$ & $3.62 \pm 0.37^{\mathrm{Aa}}$ \\
\hline \multirow{2}{*}{ HM4 } & $3.83 \pm 0.52^{\mathrm{Aab}}$ & $4.17 \pm 0.41^{\mathrm{Aa}}$ & $4.17 \pm 0.26^{\mathrm{Aa}}$ & $3.62 \pm 0.37^{\mathrm{Ab}}$ \\
\hline & \multicolumn{4}{|c|}{ Texture } \\
\hline $\mathrm{C}$ & $4.67 \pm 0.52^{\mathrm{ABab}}$ & $4.67 \pm 0.41^{\mathrm{Aab}}$ & $4.79 \pm 0.25^{\mathrm{Aa}}$ & $4.25 \pm 0.39^{\mathrm{Ab}}$ \\
\hline $\mathrm{I} 2$ & $4.83 \pm 0.41^{\mathrm{ABa}}$ & $4.67 \pm 0.41^{\mathrm{Aa}}$ & $4.79 \pm 0.40^{\mathrm{Aa}}$ & $4.50 \pm 0.45^{\mathrm{Aa}}$ \\
\hline I4 & $4.67 \pm 0.82^{\mathrm{ABa}}$ & $4.83 \pm 0.26^{\mathrm{Aa}}$ & $4.75 \pm 0.42^{\mathrm{Aa}}$ & $4.62 \pm 0.37^{\mathrm{Aa}}$ \\
\hline HM2 & $5.00 \pm 0.00^{\mathrm{Aa}}$ & $4.42 \pm 0.49^{\mathrm{Ab}}$ & $4.67 \pm 0.52^{\mathrm{Aab}}$ & $4.25 \pm 0.39^{\mathrm{Ab}}$ \\
\hline \multirow[t]{2}{*}{ HM4 } & $4.33 \pm 0.41^{\mathrm{Ba}}$ & $4.58 \pm 0.38^{\mathrm{Aa}}$ & $4.72 \pm 0.40^{\mathrm{Aa}}$ & $4.25 \pm 0.50^{\mathrm{Aa}}$ \\
\hline & \multicolumn{4}{|c|}{ Overall acceptability } \\
\hline $\mathrm{C}$ & $4.54 \pm 0.46^{\mathrm{Aa}}$ & $4.53 \pm 0.33^{\mathrm{ABa}}$ & $4.68 \pm 0.38^{\mathrm{Aa}}$ & $3.75 \pm 0.67^{\mathrm{Bb}}$ \\
\hline $\mathrm{I} 2$ & $4.67 \pm 0.52^{\mathrm{Aa}}$ & $4.68 \pm 0.38^{\mathrm{ABa}}$ & $4.65 \pm 0.23^{\mathrm{Aa}}$ & $4.38 \pm 0.37^{\mathrm{Aa}}$ \\
\hline I4 & $4.22 \pm 0.75^{\mathrm{Aab}}$ & $4.79 \pm 0.25^{\mathrm{Aa}}$ & $4.56 \pm 0.33^{\mathrm{Aab}}$ & $4.05 \pm 0.64^{\mathrm{ABb}}$ \\
\hline HM2 & $4.50 \pm 0.45^{\mathrm{Aa}}$ & $4.30 \pm 0.57^{\mathrm{ABab}}$ & $4.38 \pm 0.44^{\mathrm{Aab}}$ & $3.88 \pm 0.19^{\mathrm{ABb}}$ \\
\hline HM4 & $4.08 \pm 0.20^{\mathrm{Aa}}$ & $4.17 \pm 0.41^{\mathrm{Ba}}$ & $4.23 \pm 0.36^{\mathrm{Aa}}$ & $4.17 \pm 0.23^{\mathrm{ABa}}$ \\
\hline
\end{tabular}

C: probiotic yoghurt with no supplement; I2: probiotic yoghurt fortified with 2\% inulin; I4: probiotic yoghurt fortified with $4 \%$ inulin; HM2: probiotic yoghurt fortified with $2 \%$ Hi-maize; HM4: probiotic yoghurt fortified with 4\% Hi-maize.

${ }^{\mathrm{a}-\mathrm{b}}$ Means \pm standard deviations in the same row with different superscript lowercase letters are significantly different $(\mathrm{P}<0.05)$

${ }^{A}-\mathrm{C}$ Means \pm standard deviations in the same column with different superscript uppercase letters are significantly different $(\mathrm{P}<0.05)$ 
of storage whereas both ingredients had no significant effect on aroma and texture throughout storage $(\mathrm{P}>0.05)$. Therefore, it can be reported that the addition ratio of ingredients was not statistically important in terms of reported sensory properties of experimental yoghurts.

In another study, probiotic yoghurt supplemented with $3 \%$ inulin had lower flavour and nonoral texture scores than those of the control sample whereas inulin addition did not significantly affect their appearance values (Heydari et al., 2011). No significant inulin effect could be observed on "firmness", which was measured as the force required for elevating a coffee spoonful of yoghurt in the study of Guggisberg et al. (2009). Similarly, Dello Staffolo et al. (2004) found no significant differences between yoghurts without inulin and with $1.3 \%$ inulin, when performing a tringle test with an untrained panel. Balthazar et al. (2015) also could not find statistical difference in appearance, smell, texture or overall liking between control ovine milk yoghurt and samples supplemented with $2 \%$ and $6 \%$ inulin.

Hi-maize supplementation of probiotic yoghurts did not alter sensory characteristics throughout storage at $4{ }^{\circ} \mathrm{C}$ when compared to the control sample. Similar to our findings, Heydari et al. (2011) determined no significant differences in flavour, appearance or non-oral texture properties between control probiotic yoghurt and a sample supplemented with $1.5 \%$ Hi-maize.

Storage period had no effect $(\mathrm{P}>0.05)$ on sensory characteristics of experimental yoghurts generally. However, significant reductions $(\mathrm{P}<0.05)$ in taste, appearance, aroma and overall acceptability scores of control probiotic yoghurt were determined at the end of storage when compared to the $1^{\text {st }}$ day. Similar decreases were also detected for texture and overall acceptability values of sample with $2 \% \mathrm{Hi}$ maize. Bedani et al. (2014) also noted a statistically important reduction in sensory acceptability scores for control probiotic soy yoghurt and the sample supplemented with inulin on the $21^{\text {st }}$ day of storage.

\section{Conclusions}

This study has shown the advantageous use of Hi-maize in the fortification of set-type probiotic yoghurt when compared to yoghurt fortified with inulin which was dose-dependent. The supplementation of probiotic yoghurt with 2\% Hi-maize seems to be a good alternative for obtaining a functional dairy product with desired textural properties. In addition, firmness of this sample improved during the storage period whereas apparent viscosity values remained statistically constant. Probiotic yoghurts supplemented with either inulin or Hi-maize had higher taste and overall acceptability scores than the control sample, especially at the end of storage. Moreover, all samples kept their stability throughout the storage period in terms of sensory characteristics.

\section{Utjecaj dodatka inulina i rezistentnog škroba na teksturu i senzorska svojstva probiotičkog jogurta}

\section{Sažetak}

Cilj ovog rada bio je istražiti utjecaj dodatka inulina i rezistentnog škroba na teksturu i senzorska svojstva tijekom 21 dana skladištenja probiotičkog jogurta, koji je sadržavao soj Lactobacillus acidophilus. Tekstura je analizirana određivanjem čvrstoće, adhezivnosti i prividne viskoznosti. Mlijeko namijenjeno za proizvodnju jogurta obogaćivano je dodatkom $2 \%$ ili $4 \%$ inulina, odnosno rezistentnog škroba, dok kontrolni uzorak nije bio obogaćivan. Uz iznimku s početka perioda čuvanja, jogurt obogaćen dodatkom 2 \% rezistentnog škroba bio je čvršći u odnosu na jogurt obogaćen istom količinom inulina. Nisu utvrđene značajne razlike u čvrstoći uzoraka jogurta obogaćenih dodatkom $4 \%$ inulina, odnosno $4 \%$ rezistentnog škroba. Osim toga, količina dodanog inulina, odnosno rezistentnog škroba, nije utjecala niti na adhezivnost jogurta. Dodatak $2 \%$ inulina odnosno rezistentnog škroba uglavnom nije utjecao na promjenu viskoznosti jogurta tijekom perioda čuvanja. Senzorska analiza uključivala je ocjenjivanje okusa, izgleda, arome, teksture i ukupne prihvatljivosti. Općenito nisu utvrđene značajnije razlike u senzorskim svojstvima jogurta obogaćenog inulinom odnosno rezistentnim škrobom. $\mathrm{Na}$ senzorske ocjene nisu utjecali niti količina dodatka niti period čuvanja. Međutim, na kraju perioda čuvanja utvrđene su značajno niže $(\mathrm{P}<0,05)$ ocjene za okus, izgled, aromu i ukupnu prihvatljivost u odnosu na prvi dan čuvanja.

Ključne riječi: probiotički jogurt, prebiotici, tekstura, senzorska svojstva 


\section{References}

1. Akalın, A.S., Unal, G., Gonc, S., Fenderya, S. (2008): Effects of whey protein concentrate and fructooligosaccharide on the rheological and sensory properties of reduced-fat probiotic yoghurt. Milchwissenschaft 63 (2), 171-174.

2. Akalın, A.S., Ünal, G. (2010): The influence of milk supplementation on the microbiological stability and textural characteristics of fermented milk. Milchwissenschaft 65 (3), 291-294.

3. Amatayakul, T., Halmos, A.L., Sherkat, F., Shah, N.P. (2006): Physical characteristics of yoghurts made using exopolysaccharide producing starter cultures and varying casein to whey protein ratios. International Dairy Journal 16, 40-51. https://doi.org/10.1016/j.idairyj.2005.01.004

4. Antunes, A.E.C., Antunes, A.J., Cardello, H.M.A.B. (2004): Chemical, physical, microstructural and sensory properties of set fat-free yogurts stabilized with whey protein concentrate. Milchwissenshaft 59, 161-165.

5. AOAC. (2006): Official Methods of Analysis. 18th ed. Association of Official Analytical Chemists, Arlington, USA.

6. Balthazar, C.F., Gaze, L.V., Da Silva, H.L.A., Pereira, C.S., Franco, R.M., Conte-Junior, C.A., De Freitas, M.Q., De Oliveira Silva, A.C. (2015): Sensory evaluation of ovine milk yoghurt with inulin addition. International Journal of Dairy Technology 68(2), 281-290. https://doi.org/10.1111/1471-0307.12189

7. Bedani, R., Campos, M.M.S., Castro, I.A., Rossi, E.A., Saad, S.M.I. (2014): Incorporation of soybean by-product okara and inulin in a probiotic soy yoghurt: texture profile and sensory acceptance. Journal of the Science of Food Agriculture 94, 119-125. https://doi.org/10.1002/jsfa.6212

8. Bonczar, G., Wszolek, M., Siuta, A. (2002): The effects of certain factors on the properties of yoghurt made from ewe's milk. Food Chemistry 79, 85-91. https://doi.org/10.1016/S0308-8146(02)00182-6

9. Damin, M.R., Minowa, E., Alcântara, M.R., Oliveira, M.N. (2008): Effect of cold storage on culture viability and some rheological properties of fermented milk prepared with yogurt and probiotic bacteria. Journal of Texture Studies 39, 40-55. https://doi.org/10.1111/j.1745-4603.2007.00129.x

10. Dave, R.I., Shah, N.P. (1998a): Ingredient supplementation effects on viability of probiotic bacteria in yogurt. Journal of Dairy Science 81, 2804-2816. https://doi.org/10.3168/jds.S0022-0302(98)75839-4

11. Dave, R.I., Shah, N.P. (1998b): The influence of ingredient supplementation on the textural characteristics of yogurt. Australian Journal of Dairy Technology 53, 180184.

12. de Souza Oliveira, R.P., Perego, P., de Oliveira, M.N., Converti, A. (2011): Effect of inulin as prebiotic and symbiotic interactions between probiotics to improve fermented milk firmness. Journal of Food Engineering 107, 36-40. https://doi.org/10.1016/j.jfoodeng.2011.06.005
13. Dello Staffolo, M., Bertola, N., Martino, M., Bevilacqua, A. (2004): Influence of dietary fiber addition on sensory and rheological properties of yoghurt. International Dairy Journal 14, 263-268. https://doi.org/10.1016/j.idairyj.2003.08.004

14. Guggisberg, D., Cuthbert-Steven, J., Piccinali, P., Bütikofer, U., Eberhard, P. (2009): Rheological, microstructural and sensory characterization of low-fat and whole milk set yoghurt as influenced by inulin addition. International Dairy Journal 19, 107-115. https://doi.org/10.1016/j.idairyj.2008.07.009

15. Guzmán-González, M., Morais, F., Ramos, M., Amigo, L. (1999): Influence of skimmed milk concentrate replacement by dry dairy products in a low fat set-type yoghurt model system. I: Use of whey protein concentrates, milk protein concentrates and skimmed milk powder. Journal of the Science of Food and Agriculture 79, 1117-1122. https://doi.org/10.1002/(SICI)1097-0010(199906)79: $8<1117:: A I D-J S F A 335>3.0 . C O ; 2-F$

16. Hasani, S., Khodadadi, I., Heshmati, A. (2016): Viability of Lactobacillus acidophilus in rice bran-enriched attired yoghurt and the physicochemical and sensory characteristics of product during refrigerated storage. International Journal of Food Science and Technology 51, 2485-2492. https://doi.org/10.1111/ijfs.13230

17. Heydari, S., Mortazavian, A.M., Ehsani, M.R., Mohammadifar, M.A., Ezzatpanah, H. (2011): Biochemical, microbiological and sensory characteristics of probiotic yogurt containing various prebiotic compounds. Italian Journal of Food Science 23, 153-163.

18. Homayouni, A., Amini, A., Khodavirdiv, A.K., Mortazavian, A.M., Esadeh, K., Pourmoradian, S. (2013): Resistant starch in food industry: A changing outlook for consumer and producer. Starch-Starke 65, 1-13.

19. Kailasapathy, K., Supriadi, D. (1998): Effect of partially replacing skim milk powder with whey protein concentrate on the sensory qualities of lactose hydrolysed acidophilus yogurt. Milchwissenschaft 53, 385-388.

20. Kavaz, A., Bakırc1, I. (2014): Influence of inulin and demineralized whey powder addition on the organic acid profiles of probiotic yoghurts. International Journal of Dairy Technology 67 (4), 577-583. https://doi.org/10.1111/1471-0307.12152

21. Kim, Y., Faqih, M.N., Wang, S.S. (2001): Factors affecting gel formation of inulin. Carbohydrate Polymers 46, 135-145. https://doi.org/10.1016/S0144-8617(00)00296-4

22. Kip, P., Meyer, D., Jellema, R.H. (2006): Inulins improve sensory and textural properties of low-fat yoghurts. International Dairy Journal 16, 1098-1103. https://doi.org/10.1016/j.idairyj.2005.10.011

23. Klaver, F.A.M., Kingma,. F., Weerkamp, A.H. (1993): Growth and survival of Bifidobacteria in milk. Netherlands Milk Dairy Journal 47, 151-164.

24. Lucey, J.A., Singh, H. (1997): Formation and physical properties of acid milk gels: a review. Food Research International 30 (7), 529-542. https://doi.org/10.1016/S0963-9969(98)00015-5 
25. Marafon, A.P., Sumi, A., Alcântara, M.R., Tamime, A.Y., Oliveira, M.N. (2011): Optimization of the rheological properties of probiotic yoghurts supplemented with milk proteins. Lebensmittel Wissenschaft Technologie 44, 511-519. https://doi.org/10.1016/j.lwt.2010.09.005

26. Martin-Diana, A.B., Janer, C., Pelaez, C., Requena, T. (2003): Development of a fermented milk containing probiotic bacteria. International Dairy Journal 13, 827-833. https://doi.org/10.1016/S0958-6946(03)00117-1

27. Modzelewska-Kapitula, M., Klebukowska, L. (2009): Investigation of the potential for using inulin HPX as a fat replacer in yoghurt production. International Journal of Dairy Technology 62 (2), 209-214. https://doi.org/10.1111/j.1471-0307.2009.00481.x

28. Mohammadi, R., Mortazavian, A.M. (2011): Review Article: Technological Aspects of Prebiotics in Probiotic Fermented Milks. Food Reviews International 27, 192-212. https://doi.org/10.1080/87559129.2010.535235

29. Nguyen, P.T.M., Kravchuk, O., Bhandari, B., Prakash, S. (2017): Effect of different hydrocolloids on texture, rheology, tribology and sensory perception of texture and mouthfeel of low-fat pot-set-yoghurt. Food Hydrocolloids 72, 90-104. https://doi.org/10.1016/j.foodhyd.2017.05.035

30. Pimentel, T.C., Garcia, S., Prudencio, S.H. (2012): Probiotic yoghurt with inulin-type fructans of different degrees of polymerization: physicochemical and microbiological characteristics and storage stability. Semina: Ciências Agrárias 33 (3), 1059-1069. https://doi.org/10.5433/1679-0359.2012v33n3p1059

31. Ramchandran, L., Shah, N.P. (2008): Growth, proteolytic, and ACE-I activities of Lactobacillus delbrueckii ssp. bulgaricus and Streptococcus thermophilus and rheological properties of low fat yogurt as influenced by the addition of Raftiline HP. Journal of Food Science 73, M368-M374. https://doi.org/10.1111/j.1750-3841.2008.00889.x
32. Renner, E. (1993): Milchpractikum, pp. 9-10. Giessen, Germany: Justus-Liebig-Universita.

33. Sandoval-Castilla, O., Lobato-Calleros, C., AguirreMandujano, E., Vernon- Carter, E.J. (2004): Microstructure and texture of yogurt as influenced by fat replacers. International Dairy Journal 14, 151-159. https://doi.org/10.1016/S0958-6946(03)00166-3

34. Sodini, I., Lucas, A., Oliveira, M.N., Remeuf, F., Corrieu, G. (2002): Effect of milk base and starter culture on acidification, texture, and probiotic cell counts in fermented milk processing. Journal of Dairy Science 85, 2479-2488. https://doi.org/10.3168/jds.S0022-0302(02)74330-0

35. Srisuvor, N., Chinprahast, N., Prakitchaiwattana, C., Subhimaros, S. (2013): Effects of inulin and polydextrose on physicochemical and sensory properties of low-fat set type yoghurt with probiotic-cultured banana purée. LWT-Food Science and Technology 51, 30-36. https://doi.org/10.1016/j.lwt.2012.10.018

36. Stijepic, M., Glusac, J., Durdevic-Milosevic, D., PesicMikulec, D. (2013): Physicochemical characteristics of soy probiotic yoghurt with inulin addition during refrigerated storage. Romanian Biotechnological Letters 18 (2), 8077-8085.

37. Tamime, A.Y. (2005): Probiotic Dairy Products, vol. 1. Blackwell Publishing, Oxford, UK.

38. Turkish Yoghurt Standard (1989): TSE 1330. Ankara, Turkey: Turkish Standard Institute.

39. Wang, C., Gao, F., Zhang, T., Wang, Y., Guo, M. (2015): Physicochemical, textural, sensory properties and probiotic survivability of Chinese Laosuan Nai (protein-fortified set yoghurt) using polymerized whey protein as a co-thickening agent. International Journal of Dairy Technology 68 (2), 261-269. https://doi.org/10.1111/1471-0307.12186 